\title{
Incomplete oral sanation as a risk factor for elevated leucocytosis and postoperative infection
}

\author{
Janusz Konstanty-Kalandyk ${ }^{1}$, Aleksandra Kalandyk-Konstanty², Bogusław Kapelak ${ }^{1}$, Joanna Zarzecka², \\ Rafal Drwila ${ }^{3}$, Agnieszka Kieltyka ${ }^{4}$, Jacek Piątek ${ }^{1}$, Krzysztof Bartuś ${ }^{1}$, Jerzy Sadowski ${ }^{1}$ \\ 'Department of Cardiovascular Surgery and Transplantology, John Paul II Hospital, Krakow, Poland \\ ${ }^{2}$ Department of Conservative Dentistry and Endodontics, Jagiellonian University Collegium Medicum, Krakow, Poland \\ ${ }^{3}$ Department of Anaesthesiology and Intensive Care, John Paul II Hospital, Krakow, Poland \\ ${ }^{4}$ Chair of Epidemiology and Preventive Medicine, Jagiellonian University Collegium Medicum, Krakow, Poland
}

\begin{abstract}
Background: Patients after cardiac surgery are particularly at risk of infections. The oral cavity is a potential source of bacteria. Aim: To assess of influence of incomplete oral sanation on the probability of occurrence of infection in the postoperative period. Methods: The study subjects $(n=240)$ were patients undergoing cardiac surgery, with $(n=185)$ and without $(n=55)$ complete oral sanation. Complete oral sanation — patients had treated and eradicated all potential inflammatory foci in the oral cavity. Dental treatment: conservative dental treatment $(70 \%)$, endodontic treatment $(30 \%)$, and surgical dental treatment (85\%), depending on treatment needs.

Results: Patients with incomplete oral cavity sanation had more infections $(7.27 \%$ vs. $1.62 \%, p=0.062)$ in the postoperative period. The risk of infection was six times higher compared to the patients with complete sanation $(p=0.042)$, which correlated with higher level of leucocytosis in the early postoperative period (10.11 vs. $\left.10.96 \times 10^{3} / \mu \mathrm{L}, \mathrm{p}=0.059\right)$.

Conclusions: Incomplete oral sanation is associated with higher levels of leucocytosis and greater risk of infection in the early postoperative period.
\end{abstract}

Key words: cardiac surgery, oral sanation, infection

Kardiol Pol 2016; 74, 10: 1167-1173

\section{INTRODUCTION}

The deterioration risk profile of patients who required cardiac surgery led to an increase incidence in post-operative complications, despite a big improvement in perioperative care and better operative techniques. Based on large studies (over 5000 patients), $15.9 \%$ of non-cardiac complications were observed after cardiac surgery. The most common complications were respiratory failure $(8.1 \%, \mathrm{n}=432)$, renal failure requiring dialysis $(5.5 \%, \mathrm{n}=295)$, infection of the sternum $(2.7 \%, \mathrm{n}=146)$, and sepsis $(2.7 \%, \mathrm{n}=143)$. Independent risk factors of death were respiratory failure and the occurrence of sepsis. [1]

Infection after heart surgery increases mortality and length of stay $[2,3]$. Patients undergoing cardiac surgery procedures appear to have an increased risk of infection, particularly dur- ing hospitalisation, because of the extent of surgical wounds, postoperative frequent use of invasive methods of treatment and diagnosis (within intra-aortic balloon pump, pulmonary artery catheterisation), and customary use of prophylactic or empiric antibiotics in the perioperative period [4]. Lack of proper treatment of potential sources of infection before surgery, including odontogenic, may affect results of treatment [5].

An important reservoir of the bacteria responsible for infection could be the oral cavity [6]. Plaque is involved in the initial process of colonisation of the mouth and is an additional source of colonisation and nosocomial infections in the Intensive Care Unit.

Terezhalmy et al. [7] studied 156 consecutive patients immediately before heart valve replacement and found that

Address for correspondence:

Janusz Konstanty-Kalandyk, MD, PhD, Department of Cardiovascular Surgery and Transplantology, John Paul II Hospital, ul. Prądnicka 80, 31-202 Kraków, Poland, e-mail: jakonstanty@poczta.onet.pl

Received: 29.08.2015 Accepted: 11.02.2016 Available as AoP: 05.05.2016

Kardiologia Polska Copyright (C Polskie Towarzystwo Kardiologiczne 2016 
$98 \%$ had periodontal disease and $15 \%$ had at least one tooth abscess detected radiologically.

During dental healthcare procedures or daily oral hygiene transient bacteraemia from oral cavity may occur. Although bacteraemia is transient, in patients with immunodeficiency or comorbidity this bacteraemia may cause extra-oral infections [8].

Objective of the study was the assessment of influence of complete oral sanation (complete removal of potential sources of infection from oral cavity) on probability of occurrence infection in postoperative period.

\section{METHODS}

Two hundred and forty consecutive patients were enrolled. In 185 cases complete oral sanation was achieved. In 55 cases, because of symptoms exacerbation, complete oral sanation was not achieved.

If the patient had symptoms exacerbation and sanation was not completed, an operation was done according to schedule, to not expose the patient to the additional risks of lengthening waiting period for surgery.

Exacerbation of symptoms (coronary disease - angina during exercise without episodes of myocardial infarction, at least once during waiting period for elective surgery, heart valve disease - shortness of breath during effort, which, according to the patient, within the last six months appeared with less and less effort).

All patients had voluntarily agreed to take dental care in the preoperative period, and during admission to the hospital they filled out a questionnaire on their health habits of oral hygiene. All dental treatment was carried out in the Department of Conservative Dentistry and Endodontics (academic centre). The number of dental treatment visits depended on the state of oral hygiene and clinical condition.

Complete oral sanation (study group A) - patients had treated and eradicated all potential inflammatory foci in the oral cavity, identified on the basis of the dental examination protocol (intraoral examination, X-ray examination). Patients underwent conservative dental treatment (70\% of patients), endodontic treatment (30\% of patients), and/or surgical dental treatment (85\% of patents), depending on the assessment of treatment needs.

All patients in both groups with either complete or incomplete sanation of oral cavity, during his first visit to the dentist had performed assessment of periodontal needs and professional hygienisation of the oral cavity (removal of bacterial biofilm, scaling).

Incomplete oral sanation (study group B) - sanation of the oral cavity had to be interrupted because of symptoms exacerbation.

To avoid any additional influence from the other potential inflammatory sources, patients undergoing urgent surgery, patients with active or history of infective endocarditis, patients after previous cardiac surgery, patients with congenital heart disease, and patients with chronic inflammatory diseases or patients on chronic pharmacological treatment, affecting the immune system, were excluded from the study.

For the purposes of this study, the following complications were defined: (i) infection (all) — all confirmed infections during hospital stay; and (ii) general infection — infection confirmed by the presence of symptoms of infection (fever $>38^{\circ} \mathrm{C}$, wheezing, leucocytosis, detection of new or existing progression of pulmonary infiltrates). Growth of the pathogen from blood, pleural fluid, or bronchoalveolar culture of the bronchial tree was considered as additional evidence of infection (according to The Centres for Disease Control (CDC) Definitions of Nosocomial Infection).

Surgical site infection - deep or superficial sternal wound infection confirmed by the presence of bacteria.

In all patients, both the surgical site infection group and the general infection group, a positive bacterial culture was obtained (surgical site infection - from a surgical wound, general infection — from blood or pleural fluid or bronchoalveolar culture of the bronchial tree).

Antibiotic - Cefazolin was routinely used in the perioperative period in all cases.

The proper leucocytosis range in our centre is 3.8$-10.0 \times 10^{3} / \mu \mathrm{L}$.

The median period of follow-up was nine days (average stay of a patient after cardiac surgery in our centre). Changes in the level of leucocytosis were analysed during a patient's stay in the Department of Intensive Care. We analysed the first three postoperative measurements of leucocytosis.

\section{Statistical analysis}

Continuous data are displayed as means with standard deviation. Categorical data are expressed as proportions. Categorical variables were analysed using the $\chi^{2}$ test or Fisher's exact test when appropriate.

In all studies, $p$-values $<0.05$ were considered statistically significant. Calculations were performed using STATA 8.0 package. Due to the small number of cases the Blackstone convention ( $\leq 0.1$ probably significant and $\leq 0.2$ possibly significant) was used in the assessment of risk factors.

\section{RESULTS}

The average age was 60 years (Table 1). 55.9\% of patients had coronary artery bypass grafting (CABG), and $34.7 \%$ had heart valve replacement (Valves). Diabetes was observed in $27.6 \%$, and $73.3 \%$ of patients had negative Methicillin-resistant Staphylococcus aureus (MRSA) cultures from the nose before surgery. In both groups (complete and incomplete sanation) the number of patients with positive MRSA culture was similar and was not statistically different.

The patients did not differ statistically in terms of baseline characteristics, and they did not differ in length of opera- 
Table 1. Baseline characteristic

\begin{tabular}{|c|c|c|c|c|}
\hline & & Study grou & & $\mathbf{P}$ \\
\hline & All & Complete sanation & Incomplete sanation & \\
\hline Number: & 240 & $77.1 \%$ & $22.9 \%$ & \\
\hline CABG & $55.9 \%$ & $53 \%$ & $69 \%$ & 0.24 \\
\hline Valves & $37.4 \%$ & $31 \%$ & $24 \%$ & 0.19 \\
\hline Other & $6.7 \%$ & $6 \%$ & $7 \%$ & 0.8 \\
\hline Age [years] & $60.3 \pm 10.1$ & $59.7 \pm 10.8$ & $61.9 \pm 7.4$ & 0.12 \\
\hline Diabetes mellitus & $27.6 \%$ & $27.1 \%$ & $29.6 \%$ & 0.2 \\
\hline Ejection fraction [\%] & 54.8 & 54.7 & 55 & 0.8 \\
\hline MRSA negative & $73.3 \%$ & $73.0 \%$ & $73.7 \%$ & 0.5 \\
\hline Chronic obstructive pulmonary disease & $5.0 \%$ & $5.4 \%$ & $3.6 \%$ & 0.11 \\
\hline Chronic kidney disease & $9.9 \%$ & $8.6 \%$ & $10.9 \%$ & 0.24 \\
\hline Data from Intensive Care Unit: & & & & \\
\hline Intensive Care Unit stay [days] & $1.8 \pm 2.8$ & $1.8 \pm 2.8$ & $1.7 \pm 2.6$ & 0.7 \\
\hline Prolonged intubation & $5.1 \%$ & $4.9 \%$ & $5.7 \%$ & 0.4 \\
\hline Heart failure & $6.5 \%$ & $7.4 \%$ & $3.8 \%$ & 0.46 \\
\hline
\end{tabular}

Data presented as \%, $p=$ not statistically significant; CABG — patients scheduled for coronary artery bypass grafting; Valves — patients scheduled for valve surgery; MRSA negative - negative culture for MRSA from the nose; MRSA — Methicillin-reststant Staphylococcus aureus

tion, length of time of intubation, amount of postoperative heart failure, or the number of other cardiac complications in the postoperative period (Table 1). All operations were done with use of cardiopulmonary bypass, through a classic sternotomy. The mean number of grafts in CABG patients was 2.3. In every case left internal mammary artery to left anterior descending artery (LAD-LIMA) was done and the remaining grafts were performed using veins. The mean time of surgery in patients with complete sanation amounted to $237 \mathrm{~min}$, and in the group with incomplete sanation $218 \min (p=0.1)$.

Complete sanation was achieved in $70 \%$ of patients in the CABG group and $83 \%$ in the Valves group. With regard to the results of a preoperative survey, $59 \%$ of patients declared regular visits to dentist at least once a year, 34\% did not go to the dentist at all, and $36 \%$ brushed their teeth once a day or less.

More infections (all) were observed in patients without complete preoperative sanation of the oral cavity (four patients vs. three patients; $7.27 \%$ vs. $1.62 \%$; $p=0.062$; probably significant; Fig. 1). Type of infection in the postoperative period: surgical site infection $-100 \%$ in complete oral sanation group and $50 \%$ in incomplete oral sanation group, general infection - $0 \%$ in complete oral sanation group and $50 \%$ in incomplete oral sanation group.

Leucocytosis levels were higher in patients with incomplete oral cavity sanation (10.96 vs. $10.11 \times 10^{3} / \mu \mathrm{L}$, $p=0.059$; probably significant; Fig. 2). After removing all cases of infection in both groups, the level of leucocytosis remains higher in the group of patients with incomplete oral

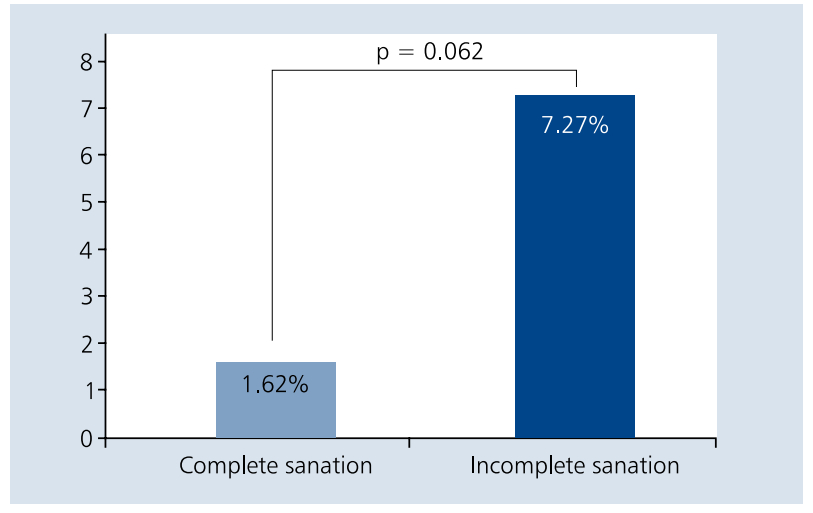

Figure 1. Postoperative infection

sanation (10.98 vs. $10.13 \times 10^{3} / \mu \mathrm{L}, \mathrm{p}=0.061$; probably significant; Fig. 3).

Independent risk factors for infection were incomplete oral sanation (odds ratio 6.1, $\mathrm{p}=0.042$ ) and diabetes mellitus (odds ratio 5.38, $p=0.059$ ) in the preoperative period (Table 2).

The results from the survey are presented in Table 3. 59\% of patients go to the dentist less often than once a year and $36 \%$ brush their teeth once a day or less.

\section{DISCUSSION}

Periodontal disease is a chronic infection caused by the most common gram-negative bacteria. It is estimated that the disease affects $75 \%$ of adults in the United States and 20-30\% of the disease is in an advanced form [9]. 


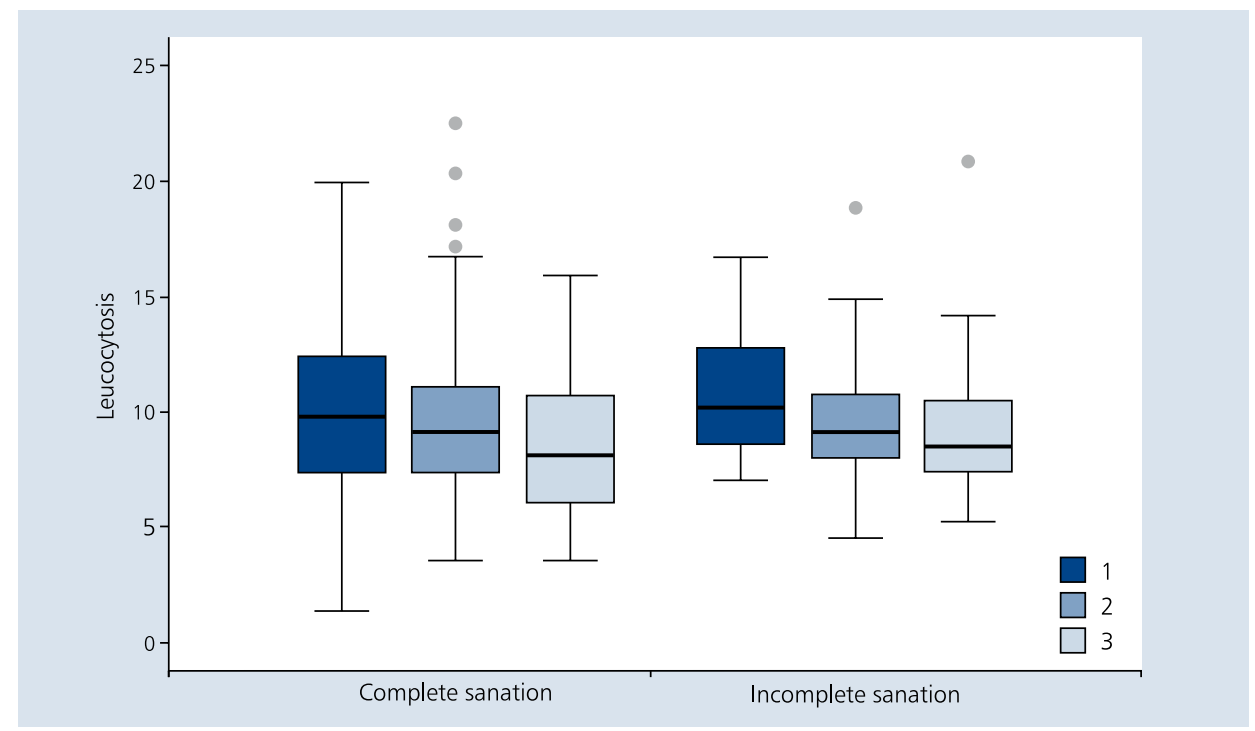

Figure 2. Leucocytosis level in whole group (1, 2, 3- subsequent postoperative measurements of leucocytosis)

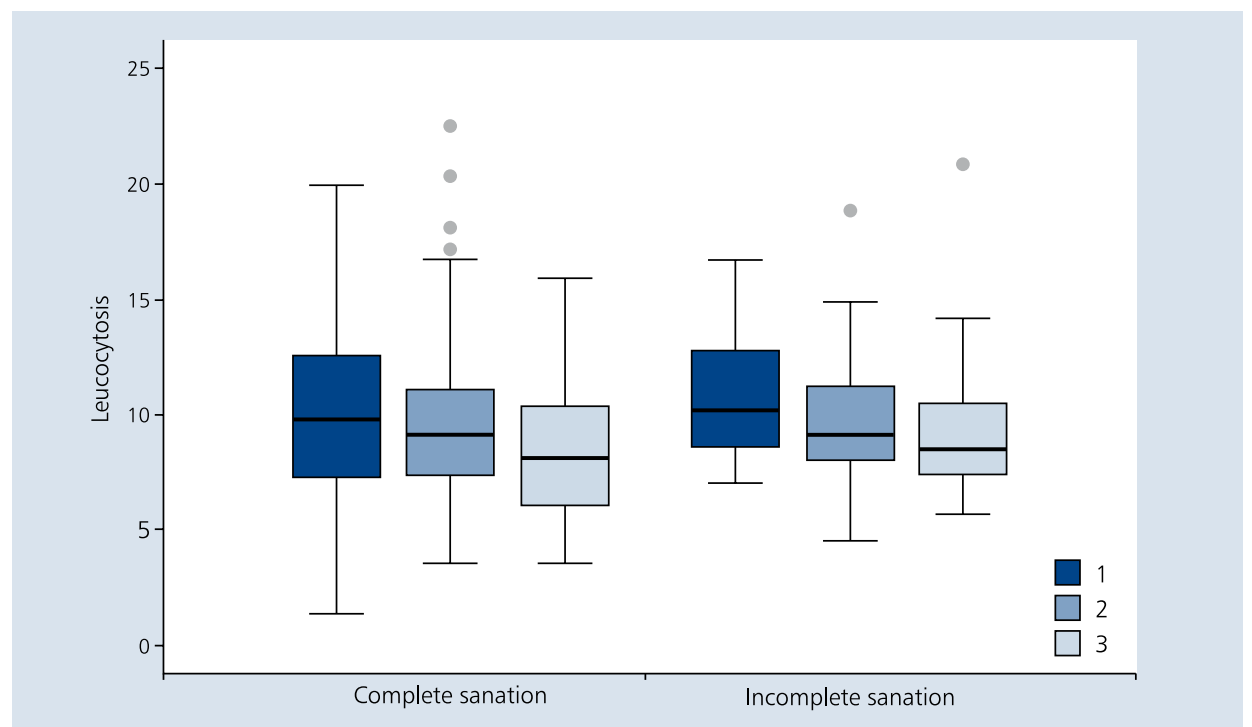

Figure 3. Leucocytosis level after removing all cases of infection (1, 2, 3- subsequent postoperative measurements of leucocytosis)

Table 2. Risk indicators of infection in the study group estimated using multivariate logistic regression

\begin{tabular}{|lccc|} 
& $\begin{array}{c}\text { Odds } \\
\text { ratio }\end{array}$ & $\begin{array}{c}\text { 95\% confidence } \\
\text { interval }\end{array}$ & $\mathbf{P}$ \\
\hline Incomplete sanation & 6.10 & $1.06-35.00$ & 0.042 \\
Age & 2.14 & $0.67-6.85$ & 0.196 \\
Diabetes mellitus & 5.38 & $0.93-30.93$ & 0.059 \\
\hline
\end{tabular}

Transient bacteraemia from the oral cavity may occur as a result of dental healthcare procedures but also as a result of daily gestures. The risk of transient bacteraemia is related to oral cavity bacterial load and to the severity of inflammation in the oral cavity [8]. Most infections of the blood in the postoperative period are classified as primary infection (unidentified source of infection). Healthy adults do not have clinical consequences of episodes of transient bacteraemia. However, for patients with weakened immune systems, in serious condition after surgery, who may have other medical conditions and are more susceptible to colonisation by bacteria, transient bacteraemia may be a more significant problem. In immunocompromised persons, common microorganisms can find favourable conditions for settlement and development [10]. 
Table 3. Survey results

\begin{tabular}{lcc} 
Survey & All & Sanation \\
\cline { 2 - 3 } & & Complete \\
\hline A visit to the dentist less than once a year & $59.0 \%$ & $59.8 \%$ \\
Brush teeth once a day or less & $36.0 \%$ & $32.0 \%$ \\
\hline
\end{tabular}

There are several defined symptoms of bacteraemia. These include fever, elevated C-reactive protein (CRP), and elevated levels of leucocytosis [11].

Thus, elevated white blood cells counts may indicate the presence of transient bacteraemia. In our study, the level of leucocytosis in patients who did not have the full eradication of potential inflammatory sources in the oral cavity was higher (probably significant).

Even after removing from the database all confirmed cases of postoperative infection, the level of leukocyte in the group of patients with incomplete oral sanitation remained higher. Therefore, we may suppose that in the perioperative period, transient bacteraemia occur, originating from a source of potential inflammatory foci in the oral cavity.

Of course, cardiac surgery, especially the length of use of extracorporeal circulatory can stimulate a systemic inflammatory response [12]. In both groups (complete and incomplete sanation of the oral cavity) duration of surgery, extracorporeal circulatory time, and the number of cardiac complications (for example, heart failure, low-cardiac output) did not differ statistically and did not have impact on the level of leucocytosis. Similarly, all patients who had preoperative risk factors that may have affected inflammatory response, including the level of leucocytosis, were excluded from the study.

Positive MRSA cultures are a risk factor for infection in the perioperative period. A lack of negative cultures of MRSA before surgery increases the incidence of infection in the whole group, but due to the lack of statistical differences in the incidence of negative MRSA cultures between the groups before surgery, they do not influence the differences in the incidence of leucocytosis and postoperative infection.

Oral bacteria have developed aggressive mechanisms to invade and persist in the host cells, to escape host immune surveillance, to adapt to niches at extra-oral sites, and to induce inflammatory responses leading to adverse systemic effects [13]. The presence of potential sources in the oral cavity can induce inflammatory response, which may allow bacteria present in body development, causing strain-specific infections. Particularly exposed are patients with weakened immune system, for example after cardiac surgery.

An important, potential focus of inflammation in the oral cavity are periodontal disease. Periodontal disease can be divided into gingivitis (plaque induced or non-plaque induced gingival lesions) and periodontitis, a bacterially induced, localised, chronic inflammatory disease, destroys connective tissue and bone that support the teeth [14-16].

The correlations between parameters of periodontitis and inflammatory markers is well established. Włosowicz et al. [17] proved relationship between higher concentration of inflammatory markers (CRP, fibrinogen) and the progression of atherosclerosis (increased intima-media thickness and formation of atherosclerotic plaques). Additionally, the authors demonstrated that oral cavity status indexes had a significant influence on intima-media thickness.

Changes in the inflammatory response in patients with acute coronary syndrome (ACS) also depend on the presence of periodontal disease. Czerniuk et al. [18] revealed a tend towards higher mean values of serum concentrations of interleukin-1 in the acute phase of ACS. Higher values of interleukin-1 and tumour necrosis factor-alpha were observed also in the long term [18].

Longer diminution of inflammatory response after ACS, in the long-term observation period, was also demonstrated by the monitoring of high sensitivity CRP concentrations in patients with more advanced periodontal disease [19].

Treatment of periodontal disease improves endothelial function and reduces the level of high sensitivity CRP in patients with periodontal disease, especially in people with cardiovascular disease and/or diabetes [20].

The PAVE study showed that periodontal treatment decreases the serum concentration of CRP in the blood, and the effect was observed six months after treatment (odds ratio 0.26 ; 95\% confidence interval: 0.09-0.72) [21, 22]. In our study, all patients (complete and incomplete sanation) had professional hygienisation during a first visit to the dentist. In the group with complete sanation the periodontal status improved, but in the incomplete sanation group, due to the impossibility to complete periodontal treatment, the improvement was less. The difference did not reach statistical significance $(p=0.1)$ because both groups had done the basic periodontal treatment (scaling and removing bacterial biofilm), which resulted in improvement of periodontal status in both groups, including patients in the incomplete sanation group.

Proper oral cavity sanation and removal of all potential foci of inflammation in the oral cavity is very important if we analyse the results of the survey (Table 3). Almost $60 \%$ of patients go to the dentist at least once a year and $36 \%$ brush their teeth once a day or not at all. We suppose that 
the condition of oral health in this group of patients is bad and the removal of all potential foci of inflammation from oral cavity will require a longer time and major commitment from dentists.

Therefore, proper cooperation in interdisciplinary team, cardiologist-dentist is crucial.

The need for close collaboration between the cardiologist, dentist, and periodontologist was recommended very often $[16,23]$.

Patients with incomplete oral sanation had more infections in the postoperative period, as compared to patients in whom sanation was completed.

It is the result of an inflammatory response induced by transient bacteraemia of oral cavity origin, which enabled the development of various pathogens, which are not harmful in healthy people with an immune system that is functioning properly.

We can only prove the relationship between the bad state of oral hygiene and inflammatory response, in patients after cardiac surgery. Thus, bacterial detection methods are needed for accurate identification of specific individuals. Another important element is knowledge about the exact mechanism of action of oral bacteria in extra-oral infections and inflammation.

The results did not achieve statistical significance due to the small group of patients. However, the levels of statistical significance indicate that the relationship between improper oral hygiene and leucocytosis is probably significant.

\section{CONCLUSIONS}

Patients without complete oral sanation have higher level of leucocytosis in the early postoperative period. Incomplete oral sanation is associated with a greater number of infections in this group of patients.

\section{Acknowledgements}

Project was co-financed by the National Science Centre for Research and Development. Project title: "Dental examination in patients selected for cardiac surgery - PREVENT". Project number: 6 ZR 9 2008C/07133.

\section{Conflict of interest: none declared}

\section{References}

1. Rahmanian PB, Kröner A, Langebartels $\mathrm{G}$ et al. Impact of major non-cardiac complications on outcome following cardiac surgery procedures: logistic regression analysis in a very recent patient cohort. Interact Cardiovasc Thorac Surg, 2013; 17: 319-326. doi: 10.1093/icvts/ivt149.

2. Keon WJ, Sherrard H. Early release following cardiac surgery. Curr Opin Cardiol, 1996; 11: 599-602.

3. Fowler VG Jr, O’Brien SM, Muhlbaier LH et al. Clinical predictors of major infections after cardiac surgery. Circulation, 2005; 112: $358-365$.
4. Engelman R, Shahian D, Shemin R et al. Workforce on Evidence-Based Medicine, Society of Thoracic Surgeons. The Society of Thoracic Surgeons Practice Guideline Series: Antibiotic Prophylaxis in Cardiac Surgery, Part II: Antibiotic Choice. Ann Thorac Surg, 2007; 83: 1569-1576.

5. Yasny JS, White J. Dental considerations for cardiac surgery. J Card Surg, 2009; 24: 64-68. doi: 10.1111/j.1540-8191.2008. 00708.x.

6. Paju S, Scannapieco FA. Oral biofilms, periodontitis, and pulmonary infections. Oral Dis, 2007; 13: 508-512.

7. Terezhalmy GT, Safadi TJ, Longworth DL, Muehrcke DD. Oral disease burden in patients undergoing prosthetic heart valve implantation. Ann Thorac Surg, 1997; 63: 402-404.

8. Perez-Chaparro PJ, Meuric V, De Mello G, Bonnaure-Mallet M. [Bacteremia of oral origin]. Rev Stomatol Chir Maxillofac, 2011; 112: 300-303. doi: 10.1016/j.stomax.2011.08.012.

9. Humphrey LL, Fu R, Buckley DI et al. Periodontal disease and coronary heart disease incidence: a systematic review and meta-analysis. J Gen Intern Med, 2008; 23: 2079-2086. doi: 10.1007/s11606-008-0787-6.

10. Li X, Kolltveit KM, Tronstad L, Olsen I. Systemic diseases caused by oral infection. Clin Microbiol Rev, 2000; 13: 547-558.

11. Jaffe DM1, Fleisher GR. Temperature and total white blood cell count as indicators of bacteremia. Pediatrics, 1991; 87: 670-674.

12. Lindman BR, Goldstein JS, Nassif ME et al. Systemic inflammatory response syndrome after transcatheter or surgical aortic valve replacement. Heart, 2015; 101: 537-545. doi: 10.1136/heartjnl-2014-307057.

13. Han $\mathrm{Y}$ W, Wang X Oral bacteria in extra-oral Infections and Inflammation. J Dent Res, 2013; 92: 485-491. doi: 10.1177/0022034513487559.

14. Friedewald VE, Kornman KS, Beck JD et al. The American Journal of Cardiology and Journal of Periodontology Editors' Consensus: periodontitis and atherosclerotic cardiovascular disease. Am J Cardiol, 2009; 104: 59-68.

15. 1999 International Workshop for a Classification of Periodontal Diseases and Conditions. Papers. Oak Brook, Illinois, October 30 - November 2, 1999. Ann Periodontol, 1999; 4: i, 1-112.

16. Czerniuk MR, Eickholz P, Grötz KA Oral cavity infections: why should cardiologists care about them? Kardiol Pol, 2015; 73: 901-908. doi: 10.5603/KP.2015.0188.

17. Włosowicz M, Wożakowska-Kapłon B, Górska R. Periodontal disease in relation to selected parameters of the cardiovascular system in a group of patients with stable angina pectoris. Cent Eur J Immunol, 2014; 39: 181-186. doi:10.5114/ceji.2014.43720.

18. Czerniuk MR, Górska R, Filipiak KJ, Opolski G. Inflammatory response to acute coronary syndrome in patients with coexistent periodontal disease. J Periodontol, 2004; 75: 1020-1026.

19. Czerniuk MR, Górska R, Filipiak KJ, Opolski G.C-reactive protein in patients with coexistent periodontal disease and acute coronary syndromes. J Clin Periodontol, 2006; 33: 415-420.

20. Teeuw WJ1, Slot DE, Susanto H et al. Treatment of periodontitis improves the atherosclerotic profile: a systematic review and meta-analysis. J Clin Periodontol, 2014; 41: 70-79. doi: 10.1111/jcpe.12171.

21. Offenbacher S, Beck JD, Moss K et al. Results from the Periodontitis and Vascular Events (PAVE) Study: a pilot multicentered, randomized, controlled trial to study effects of periodontal therapy in a secondary prevention model of cardiovascular disease. JPeriodontol, 2009; 80: 190-201. doi: 10.1902/jop.2009.080007.

22. Górski B, Ganowicz E, Górska R Ocena przydatności trzech systemów klasyfikacyjnych chorób przyzębia w stratyfikacji ryzyka sercowo-naczyniowego Dent Med Page, 2015; 52: 281-290.

23. Wożakowska-Kapłon B, Filipiak KJ, Opolski G, Górska R. [The importance of periodontal treatment in patients with cardiovascular diseases]. Kardiol Pol, 2009; 67: 1125-1127.

Cite this article as: Konstanty-Kalandyk J, Kalandyk-Konstanty A, Kapelak B et al. Incomplete oral sanation as a risk factor for elevated leucocytosis and postoperative infection. Kardiol Pol, 2016; 74: 1167-1173. doi: 10.5603/KP.a2016.0064. 


\title{
Niekompletna sanacja jamy ustnej jako czynnik ryzyka podwyższonego poziomu leukocytozy oraz infekcji w okresie pooperacyjnym
}

\author{
Janusz Konstanty-Kalandyk ${ }^{1}$, Aleksandra Kalandyk-Konstanty ${ }^{2}$, Bogusław Kapelak ${ }^{1}$, Joanna Zarzecka ${ }^{2}$, \\ Rafal Drwila ${ }^{3}$, Agnieszka Kieltyka ${ }^{4}$, Jacek Piątek ${ }^{1}$, Krzysztof Bartuś ${ }^{1}$, Jerzy Sadowski ${ }^{1}$ \\ ${ }^{1}$ Klinika Chirurgii Serca, Naczyń i Transplantologii, Szpital im. Jana Pawła II, Kraków \\ ${ }^{2}$ Klinika Stomatologii Zachowawczej i Endodoncji, Uniwersytet Jagielloński, Collegium Medicum, Kraków \\ ${ }^{3}$ Klinika Anestezjologii I Intensywnej Terapii, Szpital im. Jana Pawła II, Kraków \\ ${ }^{4}$ Katedra Epidemiologii i Medycyny Prewencyjnej, Uniwersytet Jagielloński, Collegium Medicum, Kraków
}

\section{Streszczenie}

Wstęp: Pacjenci po operacjach kardiochirurgicznych są szczególnie narażeni na wystąpienie infekcji. Jama ustna stanowi potencjalne źródło bakterii.

Cel: Celem pracy była ocena wpływu kompletnej sanacji jamy ustnej na prawdopodobieństwo wystąpienia infekcji w okresie pooperacyjnym.

Metody: Badaniem objęto pacjentów ( $n=240)$ zakwalifikowanych do operacji kardiochirurgicznej z kompletną $(n=185)$ lub niekompletną $(n=55)$ sanacją jamy ustnej. Kompletna sanacja jamy ustnej oznaczała, że pacjenci byli leczeni i mieli usunięte wszystkie potencjalne ogniska zapalne w jamie ustnej. Sposób leczenia stomatologicznego (zachowawcze - 70\%, endodontyczne $-30 \%$, chirurgiczne $-85 \%$ ) zależał od aktualnych potrzeb terapeutycznych stwierdzonych przez badającego stomatologa.

Wyniki: Wśród pacjentów z niekompletną sanacją jamy ustnej stwierdzono więcej infekcji $(7,4 \%$ vs. 1,8\%; p = 0,062) w okresie pooperacyjnym. Ryzyko infekcji było 6-krotnie większe w porównaniu z grupą pacjentów z kompletną sanacją $(p=0,042)$, co wiąże się z podwyższonym poziomem leukocytozy we wczesnym okresie pooperacyjnym $\left(10,11 \mathrm{vs.} 10,96 \times 10^{3} / \mu \mathrm{l} ; \mathrm{p}=0,059\right)$. Wnioski: Niekompletna sanacja jamy ustnej jest przyczyną podwyższonego poziomu leukocytozy we wczesnym okresie pooperacyjnym i zwiększa ryzyko wystąpienia infekcji pooperacyjnej.

Słowa kluczowe: operacja kardiochirurgiczna, sanacja jamy ustnej, infekcja, poziom leukocytozy

Kardiol Pol 2016; 74, 10: 1167-1173 